\title{
ANALISIS RANCANG BANGUN PLTS ON-GRID HIBRID BATERAI DENGAN PVSYST PADA KANTIN TEKNIK FTUI
}

\author{
Faiz Husnayain ${ }^{1}$, Derry Luthfy ${ }^{2}$ \\ ${ }^{1,2}$ Departemen Teknik Elektro, Fakultas Teknik, Universitas Indonesia, Kampus Baru UI Depok, \\ Depok, 16424, Indonesia
}

Email:1faiz.h@ui.ac.id

\begin{abstract}
This paper aims to investigate the feasibility and viability of the on-grid solar power generation at the university canteen by using two alternative methods. The first method uses the actual daily load as the basis of the calculation for the reliability of the system, whilst, the second method uses the available area as the basis of the calculation of the power generation. This research analyses the technical feasibility and the economic viability of each possible configuration involved in the comparison process. The analysis shows that the on-grid configuration set by using the maximum available area for power generation provides the highest economic viability. The system may contribute to nearly $68.98 \%$ of the working day energy consumption and nearly $182.18 \%$ of the consumption during the weekend. The total energy generation is expected to reach the potential of $16.063 \mathrm{kWh}$ annually.
\end{abstract}

Keywords: PV on-grid, hybrid system, photovoltaic, battery backup, load profile

\begin{abstract}
ABSTRAK
Pada penelitian ini dilakukan simulasi perancangan pembangkit listrik tenaga surya (PLTS) on-grid pada Kantin Fakultas Teknik Universitas Indonesia (FTUI) dengan melakukan pengujian dengan dua metode yang berbeda. Metode pertama adalah perancangan berdasarkan profil beban harian pada kantin. Metode kedua adalah pemanfaatan area yang dapat diinstalasi oleh panel surya. Keduanya dilakukan secara ongrid dengan backup baterai. Penelitian ini bertujuan untuk melihat tingkat kelayakan teknis dan ekonomis pada perancangan PLTS. Dari hasil analisis dapat disimpulkan bahwa metode perancangan PLTS berdasarkan metode kedua, yaitu area yang tersedia untuk instalasi $P V$, menghasilkan tingkat keandalan ekonomis yang paling baik. Berdasarkan perhitungan dan asumsi yang dilakukan maka diharapkan sistem ini dapat berkontribusi menyuplai energi listrik sebesar 68,98\% terhadap beban hari kerja dan 182,18\% terhadap beban hari libur. Sistem PLTS ini dapat menghasilkan potensi energi sebesar $16.063 \mathrm{kWh}$ tiap tahunnya.
\end{abstract}

Kata kunci : PLTS on-grid, sistem hibrid, fotovoltaik, backup baterai, profil beban

\section{PENDAHULUAN}

Energi bersih dan terjangkau merupakan salah satu amanat dari 17 target capaian sustainable development goals (SDGs) [1]. Dampak langsung dari amanat tersebut terlihat pada fenomena semakin banyak dan meluasnya penggunaan fotovoltaik sebagai salah satu sumber energi alternatif [2]. Pembangkit listrik tenaga surya (PLTS) yang menggunakan teknologi PV ini merupakan salah satu kandidat yang akan menggantikan energi fosil kedepannya pada penyediaan energi baik pada beban perumahan, daerah terpencil yang belum terhubung ke jaringan listrik maupun bangunan umum lainnya seperti kantin pada suatu lembaga pendidikan [3]. Fenomena penggunaan PV yang terhubung ke jaringan listrik PLN / PV on- 
grid ini makin marak khususnya di Indonesia yang merupakan negara katulistiwa dengan ribuan pulau.

Indonesia yang merupakan negara tropis memiliki paparan energi matahari dengan intensitas maksimal selama 12 jam secara rutin sepanjang tahun dengan nilai optimal $4-5$ jam perharinya [4,5]. Selain itu, penerapan PLTS ini juga diharapkan dapat membantu meningkatkan rasio elektrifikasi serta mengurangi penggunaan energi yang bersumber pada energi fosil, terlebih bila on-grid sehingga bisa diberikan ke pengguna energi lainnya yang terhubung ke jaringan listrik saat energi yang dihasilkan melebihi penggunaan.

Pemerintah Indonesia saat ini tengah berupaya melakukan diversifikasi pada sumber energi primernya, khususnya dengan peningkatan bauran rasio energi baru terbarukan [6]. Selain itu, pemerintah juga berfokus pada pembangunan ekonomi sesuai SDGs yaitu tercapainya pertumbuhan ekonomi berkualitas melalui keberlanjutan peluang kerja dan usaha, inovasi, industri inklusif, infrastruktur memadai, energi bersih yang terjangkau dan didukung kemitraan [SDGs]. Namun untuk merealisasikan energi bersih khususnya melalui PLTS on-grid perlu dilakukan analisis desain yang matang sehingga penggunaannya dapat optimal dan sesuai dengan target yang ditetapkan [7-11]. Beberapa studi telah mengkaji desain yang optimal pada perancangan PV on-grid namun tanpa menggunakan baterai [12]. Sehingga perlu dikaji sistem perancangan $\mathrm{PV}$ on-grid yang hibrid dengan baterai sebagai back-up ketika kondisi grid sedang buruk.

Penelitian ini bertujuan untuk menganalisis perancangan PLTS on-grid yang hibrid dengan baterai melalui studi kasus pada Kantin FTUI. Analisis yang akan dilakukan mencakup analisis efisiensi dari sisi teknis maupun ekonomis. Harapannya desain PLTS ongrid ini dapat diterapkan di tempat lain, khususnya pada kantin - kantin yang ada di Indonesia.

\section{METODE PENELITIAN}

\subsection{Karakteristik Kurva PV}

Karakteristik kinerja PV dapat dilihat dari kurva karakteristik hubungan tegangan dan arus (V-I) atau Daya dan arus (P-I). Gambar 1 menunjukkan bahwa ketika PV diberi hambatan $(\mathrm{R})$, yang dimana beban $(\mathrm{R})$ memberikan garis $\mathrm{I} / \mathrm{V}=\mathrm{I} / \mathrm{R}$ secara linear. Hal ini dapat dikatakan bahwa besar beban (R) mempengaruhi output daya $(\mathrm{P})$. Bila beban memiliki nilai yang kecil maka kurva akan beroperasi pada kurva yang memiliki sumber arus konstan (short circuit) yang dapat dilihat pada daerah kurva MN. Bila beban memiliki nilai yang besar maka kurva akan beroperasi pada kurva yang memiliki tangang konstan (open circuit) yang dapat dilihat pada daerah kurva PS. Bila PV dihubungkan pada beban optimal $\left(\mathrm{R}_{\mathrm{opt}}\right)$, maka $\mathrm{PV}$ akan menghasilkan tegangan maksimal dan arus maksimal yang berarti menghasilkan daya maksimal [13].

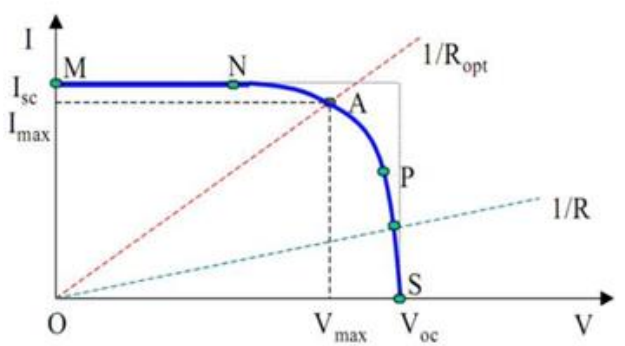

Gambar 1. Kinerja PV dalam bentuk output kurva I-V dan daya [13]

\subsection{Parameter Keluaran PV}

Dalam mengukur kinerja suatu PV, digunakan beberapa parameter-parameter yang mencakup:

a. Tegangan open - circuit $\left(\mathrm{V}_{\mathrm{OC}}\right)$

$\mathrm{V}_{\mathrm{OC}}$ merupakan variabel yang menyatakan nilai tegangan maksimum pada modul surya ketika modul surya tersebut dalam kondisi terbuka atau tidak terhubung dengan beban (open circuit). Nilai $\mathrm{V}_{\mathrm{OC}}$ akan selalu lebih besar dibanding $\mathrm{V}_{\mathrm{mp}}$, yang dimana $\mathrm{V}_{\mathrm{mp}}$ merupakan variabel tegangan operasional suatu modul surya.

b. Arus Short Circuit $\left(\mathrm{I}_{\mathrm{SC}}\right)$

ISC merupakan variabel yang menyatakan nilai arus maksimum pada modul surya ketika modul surya tersebut dalam kondisi terhubung singkat (short circuit). Nilai $\mathrm{I}_{\mathrm{Sc}}$ akan selalu lebih besar dibanding $\mathrm{I}_{\mathrm{mp}}$ yang dimana $I_{m p}$ merupakan variabel arus operasional suatu modul surya.

\section{c. Maximum Power Point (MPP)}

MPP merupakan satuan yang menyatakan daya maksimum yang bisa dihasilkan modul PV dalam keadaan operasionalnya. Karena itu MPP merupakan kombinasi perkalian dari $\mathrm{V}_{\mathrm{OC}}$ dan $\mathrm{I}_{\mathrm{SC}}$, Satuan yang digunakan untuk mendefinisikan MPP adalah Wp (Peak Watt). Perumusan MPP dapat dilihat sebagai berkut:

$$
M P P=V_{m p} \times I_{m p}
$$

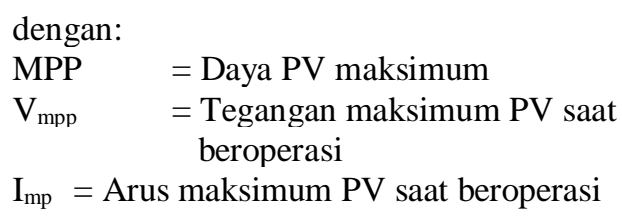

\section{d. Fill Factor}

Fill Factor merupakan perbandingan daya maksimum yang dihitung sacara teori yang dimana kombinasi perkaliannya adalah $\mathrm{V}_{\mathrm{oc}}$ dan $\mathrm{I}_{\mathrm{sc}}$ dan yang berdasarkan tegangan operasional $\left(\mathrm{V}_{\mathrm{mp}}\right)$ dan arus operasional $\left(\mathrm{I}_{\mathrm{mp}}\right)$. 
Basaran ini bisa menyatakan kualitas atau performa dari modul sel surya. Nilai Fill Factor biasanya memiliki besar sekitar 0.7 hingga 0.8. Bila nilai Fill Factor besarnya semakin dekat dengan nilai 1, maka makin bagus kualitas atau performa PV yang digunakan. Nilai Fill Factor dapat diketahui dengan perumusan sebagai berikut:

$$
F F=\frac{P_{\max }}{P_{T}}=\frac{V_{m p} \times I_{m p}}{I_{s c} \times V_{o c}}
$$

dengan:

$$
\begin{array}{ll}
\mathrm{FF} & =\text { Fill Factor } \\
\mathrm{P}_{\max } & =\text { Daya maksimum modul PV saat beroperasi } \\
\mathrm{P}_{\mathrm{T}} & =\text { Daya dengan hasil perhitungan secara teoritis } \\
\mathrm{V}_{\mathrm{mpp}} & =\text { Tegangan maksimum PV saat beroperasi } \\
\mathrm{I}_{\mathrm{mp}} & =\text { Arus maksimum PV saat beroperasi }
\end{array}
$$

\section{e. Efisiensi}

Efisiensi dalam modul PV merupakan rasio perbandingan antara daya maksimum PV pada kondisi operasional $\left(\mathrm{P}_{\max }\right)$ yang dihasilkan oleh output PV dan daya iradiasi yang dihasilkan oleh matahri dalam satuan $\mathrm{W} / \mathrm{m}^{2}$. Untuk mendapatkan nilai efisiensi suatu modul PV, bisa didapat dalam perumusan sebagai berikut:

$$
\eta=\frac{P_{\max }}{P_{\text {input }}}
$$

dengan:

$$
\begin{aligned}
& \eta \quad=\text { Nilai efisiensi } \\
& \mathrm{P}_{\max }=\text { Daya maksimum modul PV saat beroperasi } \\
& \mathrm{P}_{\text {input }}=\text { Daya iradiasi matahari }\left(\mathrm{W} / \mathrm{m}^{2}\right)
\end{aligned}
$$

\subsection{Konfigurasi Pembangkitan Energi Surya}

Sistem pembangkitan listrik tenaga surya (PLTS) tersusun dari sub-sub sistem yang diintegrasikan. Sistem PLTS memiliki metode pengintegrasian dengan konfigurasi yang berbeda yang dimana konfiguraskonfigurasi tersebut di klasifikasi menjadi 3 jenis konfigurasi:

\section{a. Pembangkitan Daya Secara Off-Grid} Pembangkitan PLTS secara off-grid bersifat independen dan biasanya dilakukan di daerah terpencil yang tidak terhubung ke dalam sistem distribusi listrik nasional (PLN). Konfigurasi ini merupakan yang paling sederhana dan jenis arus listrik yang digunakan disesuaikan dengan kebutuhan penggunaanya.

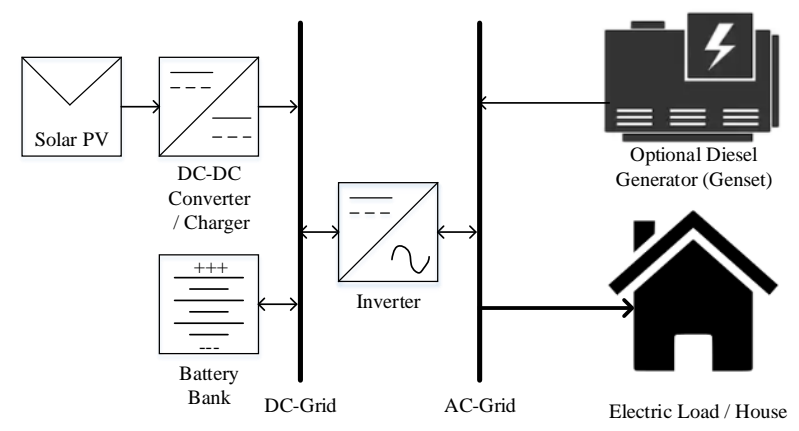

Gambar 2. Konfigurasi PLTS off grid

Untuk meningkatkan keandalan sistem, konfigurasi instalasi off-grid dapat pula digabungkan dengan keberadaan baterai yang dapat mengisi kebutuhan ketika daya pembangkitan melalui PV menurun karena siklus harian maupun kondisi cuaca. Penggambaran secara skematik sistem pembangkitan PLTS secara Off-Grid ditunjukkan dalam Gambar 2.

\section{b. Pembangkitan Daya Secara On-Grid}

Pembangkitan PLTS secara on-grid memiliki sistem jaringan yang terhubung ke dalam sistem distribusi listrik nasional (PLN). Pada konfigurasi ini tidak dibutuhkannya baterai karena jika daya yang dihasilkan PV sedang tidak optimal, maka listrik akan disuplai oleh jaringan sistem distribusi listrik nasional (PLN). Konfigurasi ini dapat menguntungkan karena beban yang ada tidak sepenuhnya bergantung kepada PLN yang dimana biaya listrik terpangkas. Penggambaran skematik PLTS secara On-Grid ditunjukkan dalam Gambar 3.

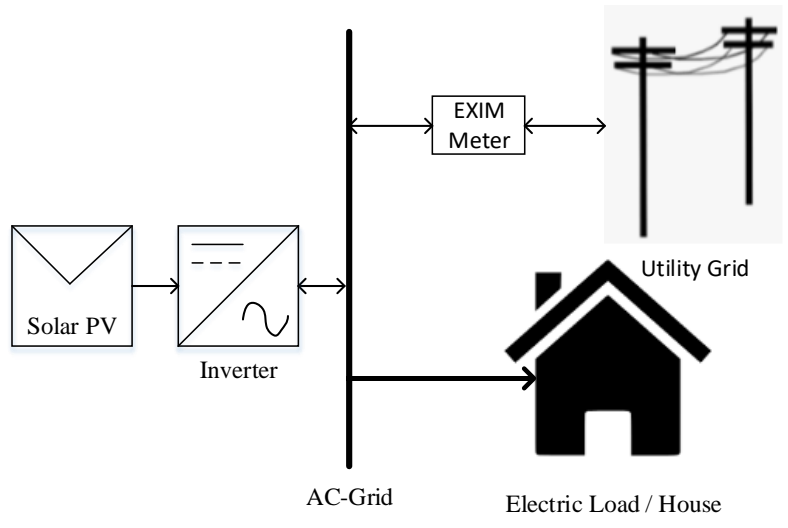

Gambar 3. Konfigurasi PLTS on-grid

\section{c. Pembangkitan Daya Hibrid dengan Battery Backup}

Pembangkitan PLTS hybrid Battery Backup bekerja dengan menggabungkan konfigurasi off-grid dan ongrid. Konfigurasi ini terhubung ke dalam sistem distribusi listrik nasional (PLN), ditambah dengan menggunakan baterai sehingga baterai tetap dapat 
menyimpan energi yang dihasilkan oleh PV pada siang hari. Oleh karena itu secara teknis konfigurasi ini lebih unggul dibanding yang lain karena kapasitas baterai tidak harus besar dan beban tidak sepenuhnya disuplai oleh PLN. Skematik pada pembangkitan PLTS hibrid battery backup terlihat pada Gambar 4.

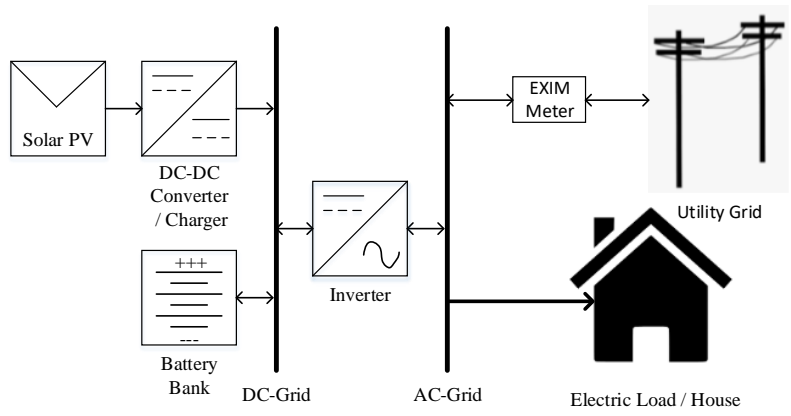

Gambar 4. Konfigurasi PLTS Battery Backup

\subsection{Langkah-langkah penyusunan spesifikasi PLTS}

Untuk mendapatkan konfigurasi yang optimal baik secara teknis kapasitas maupun biaya investasi, perancangan PLTS dilakukan melalui beberapa tahapan perancangan antara lain: pengukuran dan/atau estimasi beban daya dan periode efektif penggunaannya, pengelompokan data dan potensi, pemilihan peralatan pembangkitan energi yang akan menentukan jumlah investasi yang dilakukan, serta simulasi sebagaimana terlihat pada Gambar 5.

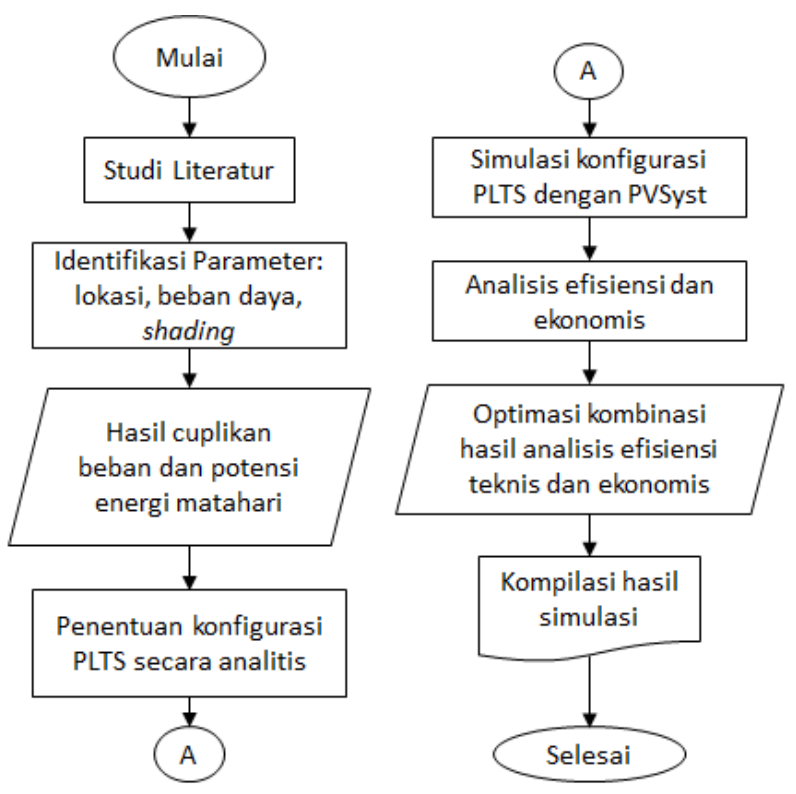

Gambar 5. Flowchart perancangan sistem PLTS on-grid

Proses perancangan PLTS secara on-grid bertujuan agar keberadaan energi yang bersumber dari PV secara otomatis akan mengurangi konsumsi energi dari PLN. Sementara itu, keberadaan baterai dalam sistem ditujukan sebagai penyimpan cadangan energi pada saat PV berada pada kondisi tidak menghasilkan energi dan energi jaringan listrik tidak tersedia. Skema umum sistem pembangkitan PLTS secara on-grid dari skema yang akan diajukan terlihat pada Gambar 6.

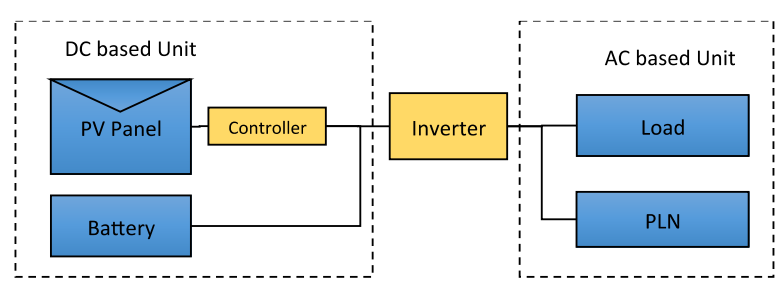

Gambar 6. Skema umum integrasi on-grid

\subsection{Metode Pengambilan Data Beban Daya}

Untuk memiliki data sampel yang valid, maka pada penelitian ini dilakukan pengambilan sampel data dalam waktu 4 hari $(24 \times 4)$ dengan interval pengambilan data tiap 1 menit. Pengukuran beban pada penelitian ini dilakukan dengan cara pemasangan alat pengukuran daya yaitu Power Quality Analyzer HIOKI 3169-20 pada panel listrik yang terletak pada Kantin FTUI seperti terlihat pada Gambar 7. Alat ini terpasang dan ditinggalkan selama proses pengukuran, kemudian data hasil pengukuran tersebut diolah dengan software yang tersedia. Setelah mendapatkan sampel data beban pada Kantin FTUI, selanjutnya dilakukan pengelompokan data berdasarkan hari kerja dan hari libur. Hal ini dikarenakan keduanya memiliki karakteristik beban yang berbeda.

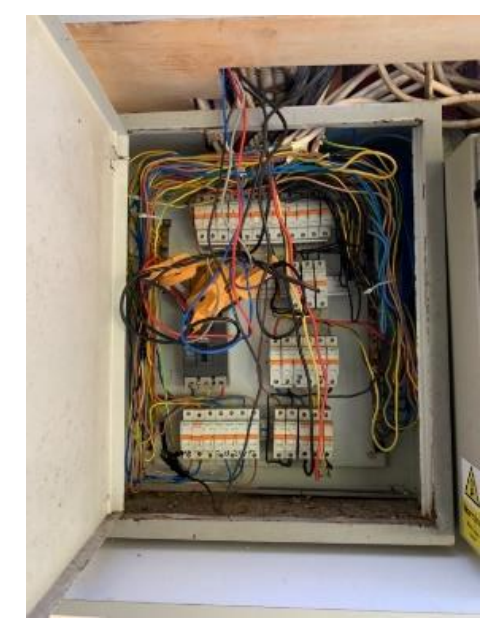

Gambar 7. Dokumentasi Pengambilan Beban Daya pada Kantin FTUI

\subsection{Rancangan Konfigurasi PLTS}

Pada penelitian ini disusun 6 alternatif konfigurasi PLTS. Penyusunan berbagai konfigurasi dilakukan untuk mencari skema yang paling optimal dalam menyuplai energi pada kantin FTUI. Variasi kombinasi 
yang disusun antara lain PV on-grid, PV off-grid, dan PV hibrid baterai on-grid baik berdasarkan total beban maupun luasan lahan tersedian untuk install PV.

\subsection{Perhitungan Perancangan PLTS}

a. Perhitungan PV Solar Array

Berdasarkan profil profil beban yang tercatat sebesar $44.969 \mathrm{kWh}$ untuk rata-rata pemakaian energi pada kantin dan diketahui bahwa jumlah faktor efisiensi dalam sistem adalah sebesar 0.8. Untuk mengetahui energi yang harus dibangkitkan, didapat pada perumusan sebagai berikut:

$$
E_{r}=\frac{\text { KonsumsiEnergiHarian }}{\text { Rata }- \text { RataEfisiensiKomponenSistem }}
$$

Energi yang dibutuhkan $\left(\mathrm{E}_{\mathrm{r}}\right)$ diperlukan untuk mengetahui daya puncak yang perlu disuplai sistem PLTS. Berdasarkan data hasil pengukuran diperoleh rata-rara minimum matahari bersinar pada permukaan kota Depok adalah 3 jam/hari. Untuk mengetahui besar daya peak didapatkan rumus:

$$
P_{\text {peak }}=\frac{E_{r}}{\text { MinimumPeakSun }}
$$

Dengan pemilihan voltase operasional pada grid DC sebesar 220 volt, maka besarnya arus yang terjadi pada saat periode pembangkitan daya maksimum adalah sebesar $\left(I_{\mathrm{DC}}\right)$ :

$$
I_{D C}=\frac{P_{P e a k}}{V_{D C}}
$$

Berdasarkan karakteristik daya pembangkitan PLTS yang diperlukan. Jumlah panel surya yang diperlukan pada konfigurasi seri adalah sebagai berikut:

$$
N_{s}=\frac{V_{D C}}{V_{\text {RatingPV }}}
$$

Sementara itu, jumlah panel surya yang terhubung secara parallel, sesuai dengan total daya yang diperlukan adalah sebagai berikut:

$$
N_{P}=\frac{P_{\text {Peak }}}{N_{S} \times P_{\text {PVModule }}}
$$

Dengan demikian, jumlah total panel surya yang akan tersusun dalam sistem PLTS di Kantin Teknik FTUI mencapai jumlah sebagai berikut:

$$
N_{\text {Total }}=N_{S} \times N_{P}
$$

b. Kapasitas Baterai

Untuk konfigurasi battery backup, kapasitas baterai terpasang secara umum dirancang menurut Days of
Autonomy yang sangat tergantung pada kebutuhan beban yang perlu disuplai. Dengan mengasumsikan bahwa kantin FTUI harus bisa mengatasi kesulitan energi secara absolut selama 1 hari penuh, maka:

$$
E_{\text {Rough }}=P_{\text {TotalPV }} \times D o A
$$

Dengan mengasumsikan bahwa beterai akan beroperasi di atas SOC, maka MDoD memiliki nilai 0.8 sehingga kapasitas aman yang perlu dapat disimpan mencapai sebegai berikut:

$$
E_{\text {safe }}=\frac{E_{\text {Rough }}}{M D o D}
$$

Setelah mendapatkan $E_{\text {Safe }}$ diperhitungkan kapasitas baterai dalam bentuk $\mathrm{AH}$ dalam permusan sebagai berikut:

$$
C=\frac{E_{\text {safe }}}{V_{\text {battery }}}
$$

Jumlah baterai yang akan disusun sesuai dengan kapasitas penyimpanan energi yang dibutuhkan adalah sebagai berikut:

$$
N_{\text {batt }}=\frac{C}{C_{\text {PerCellBatery }}}
$$

Konfigurasi seri dan parallel.

$$
\begin{gathered}
N_{\text {seri }}=\frac{V_{\text {system }}}{V_{\text {Battery }}} \\
N_{\text {Parallel }}=\frac{N_{\text {Battery }}}{N_{\text {SeriBattery }}}
\end{gathered}
$$

c. Perhitungan Inverter

Sama halnya dengan perancangan baterai, pemilihan inverter harus dilakukan sesuai dengan rancangan output daya yang akan digunakan oleh beban yang ada di Kantin FTUI. Adapun perhitungannya adalah sebagai berikut:

$$
D C-\text { ACRatio }=\frac{P_{D C}}{P_{A C}}
$$

Setelah mendapatkan DC-AC ratio, Peak Power $\left(\mathrm{P}_{\text {peak }}\right)$ dibagi oleh hasil DC-AC Ratio untuk menemukan nominal daya keluaran $\mathrm{AC}\left(\mathrm{P}_{\mathrm{AC}}\right)$.

$$
P_{\text {Nom_AC }}=\frac{P_{\text {Peak }}}{D C-\text { ACRatio }}
$$




\section{Analisis rancang bangun PLTS On-grid hybrid baterai dengan PVSYST}

Mengacu pada persamaan (4) - (17), maka didapatkan rekap jumlah PV berdasarkan skenario profil beban dan luasan area yang dapat diinstal oleh PV sebagai berikut:

Tabel 1. Jumlah komponen antar konfigurasi

\begin{tabular}{cccc}
\hline Konfigurasi & Komponen & $\begin{array}{c}\sum \text { PV (set) } \\
\text { profil beban }\end{array}$ & $\begin{array}{c}\sum \text { PV (set) } \\
\text { luasan Area }\end{array}$ \\
\hline \multirow{2}{*}{ Dengan } & n PV & 49 & 35 \\
Baterai & n Inverter & 7 & 5 \\
Tanpa & n Baterai & 5 & 5 \\
Baterai & n PV & 49 & 35 \\
\hline
\end{tabular}

\subsection{Pemodelan Simulasi PVSyst}

Dalam pemodelan perancangan sistem PLTS pada Kantin FTUI digunakan software PVsyst. Software PVSyst ini yang dapat mensimulasikan sebuah rancangan PLTS dengan kondisi nyata karena software ini telah dilengkapi database yang bersumber dari data meteorologi, selain menggunakan model komponen real seperti yang ditawarkan pada pasar eksisting.

\section{a. Penentuan Orientasi}

Langkah pertama dalam menjalankan simulasi ini, terdapat pengaturan kemiringan dan sudut azimuth dari modul PV. Hal ini bertujuan mendapatkan energi matahari secara maksimal. Hasil dari optimasi sudut kemiringan yang diproses oleh PVsyst terlihat seperti pada Gambar 8 .

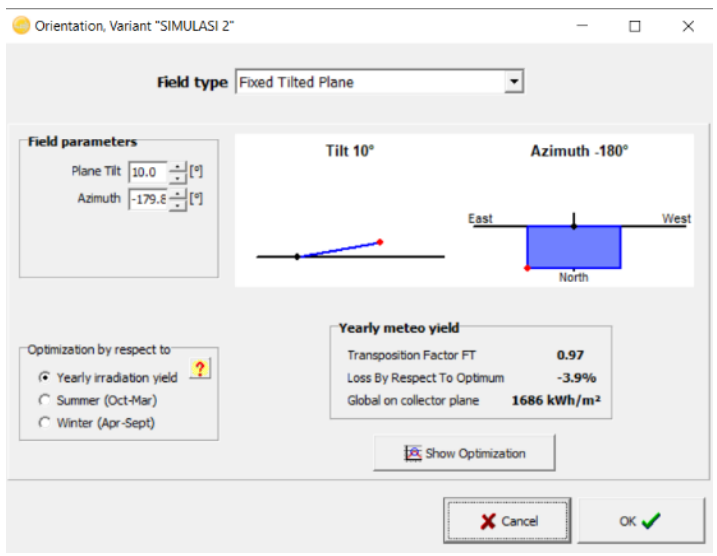

Gambar 8. Penentuan Orientasi pada PVsyst

b. Rancangan Sistem Grid pada PVsyst

Ada tiga parameter yang perlu ditetapkan dalam merancang sistem PLTS di PVSyst, antara lain Planned Power (daya yang direncanakan), pemilihan merek modul PV dan merek Inverter. Selain itu, parameter lainnya ialah mod, in series (jumlah modul dalam rangkaian seri) dan Nbre strings (jumlah string) akan otomatis terisi oleh sistem dan bisa juga diisi secara manual sebagaimana terlihat pada Gambar 9.

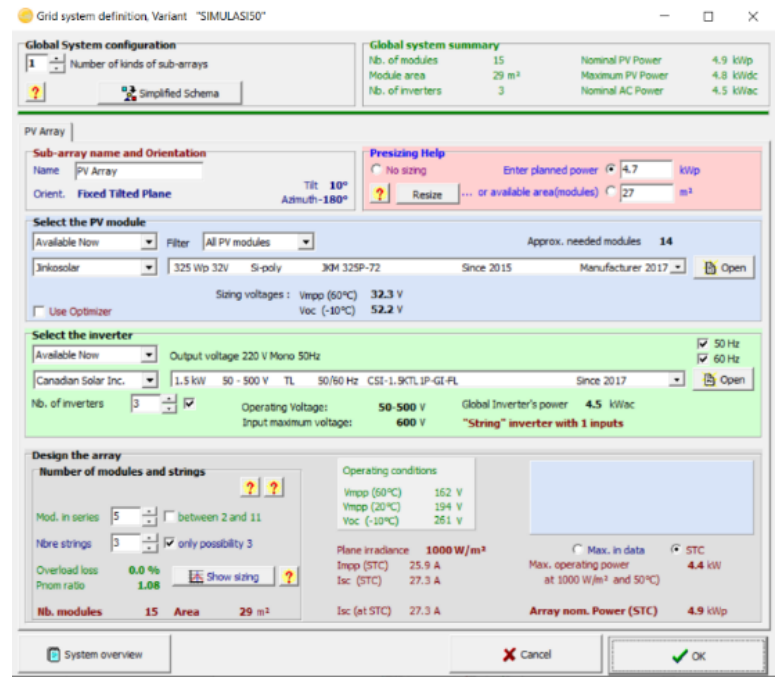

Gambar 9. Rancangan Sistem Grid pada PVSyst

Berikut ini adalah contoh pemilihan yang dilakukan untuk tiga parameter utama, yaitu tipe PV, tipe inverter dan profil beban pada kantin FTUI.

\section{Tipe PV}

Jinko dengan tipe JKM325P yang memiliki daya sebesar $325 \mathrm{Wp}$. Spesifikasi pada PVsyst terdapat pada Gambar 10.

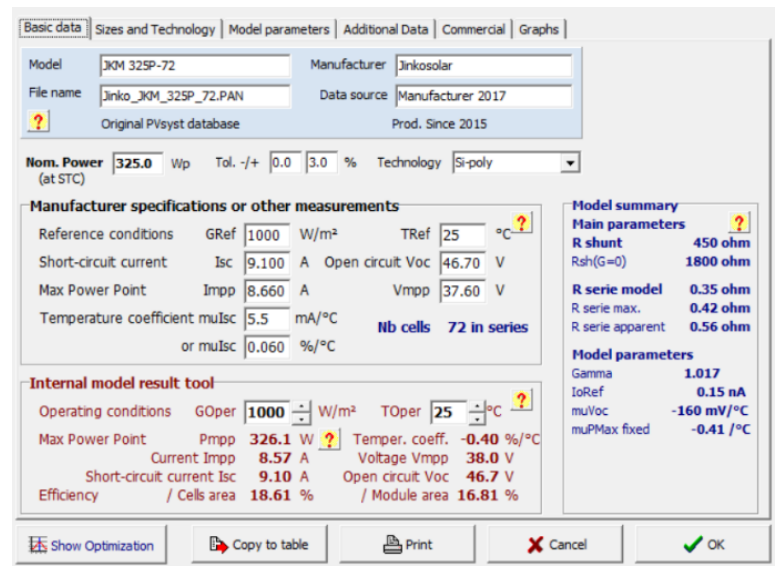

Gambar 10. Spesifikasi Jinko dengan tipe JKM325P

2. Tipe Inverter

Pada sistem ini digunakan inverter dengan merek Canadian Solar Inc. dengan tipe CSI-1-5KTL1P-GI-F seperti terlihat pada Gambar 11. 


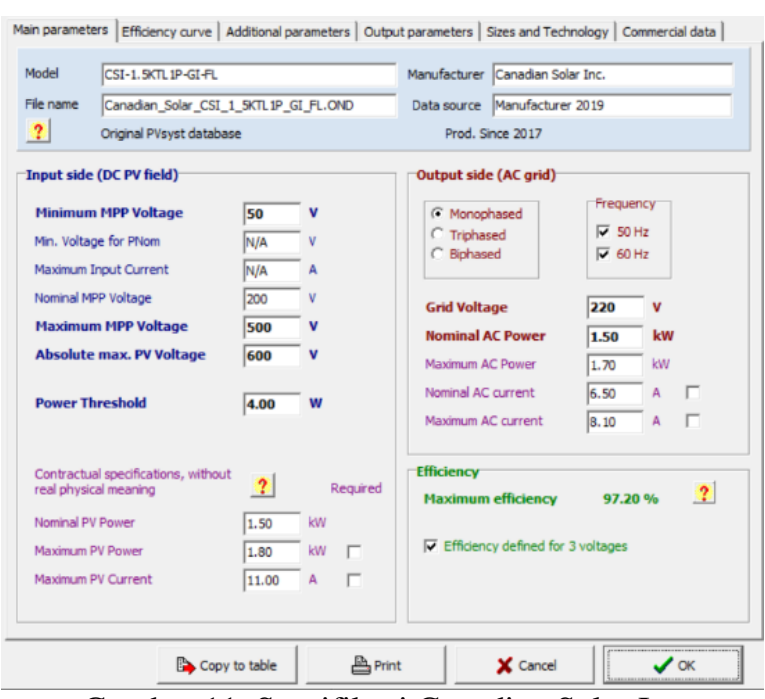

Gambar 11. Spesifikasi Canadian Solar Inc

\section{Profil Beban}

Sebagaimana telah disampaikan pada bagian sebelumnya, beban yang terdapat di kantin secara umum terdiri dari lemari pendingin yang setiap saat berada pada kondisi menyala, lampu yang sebagian kecil terus menyala dan sebagian besar mencapai beban puncak pada sore dan malam hari, serta kipas pendingin ruangan yang mencapai beban puncak pada siang hari saja. Secara grafis, siklus pembebanan yang terjadi diilustrasikan pada Gambar 12.

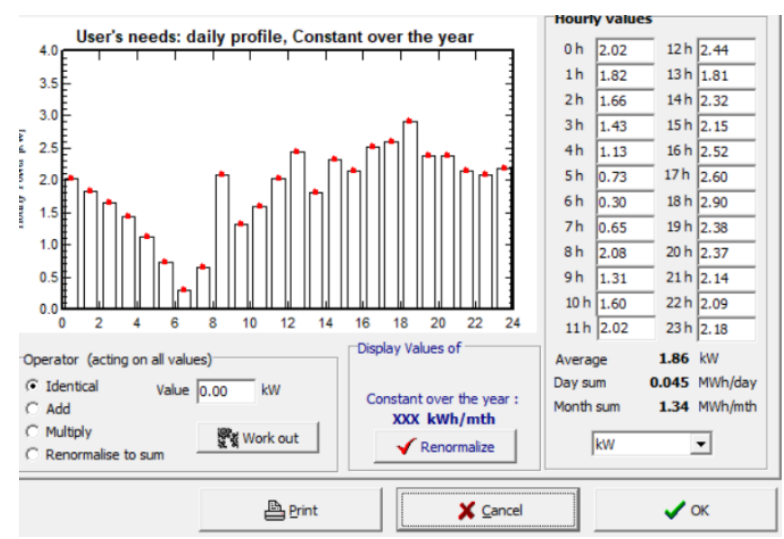

Gambar 12. Siklus pembebanan di kantin Teknik

Hasil Pengukuran Beban / Konsumsi Daya

Dalam bentuk grafik, estimasi penggunaan daya di dalam kantin secara analitis ditunjukkan pada Gambar 13. Terlihat bahwa beban maksimum terjadi pada periode siang hari diantara jam 10am sampai jam 4pm yang juga bertepatan dengan siklus maksimum pembangkitan daya oleh PV.

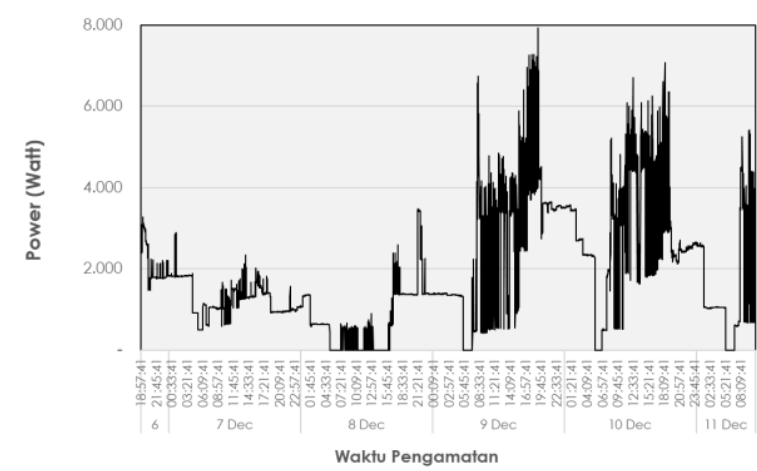

Gambar 13. Estimasi pembebanan di kantin FTUI secara analitis

Baterai (untuk konfigurasi Battery Backup)

Penggunaan baterai sebagai tempat storing energi dilakukan dengan menggunakan jenis baterai Tesla Power-wall dengan kapasitas 51 Ah seperti terlihat pada Gambar 14.

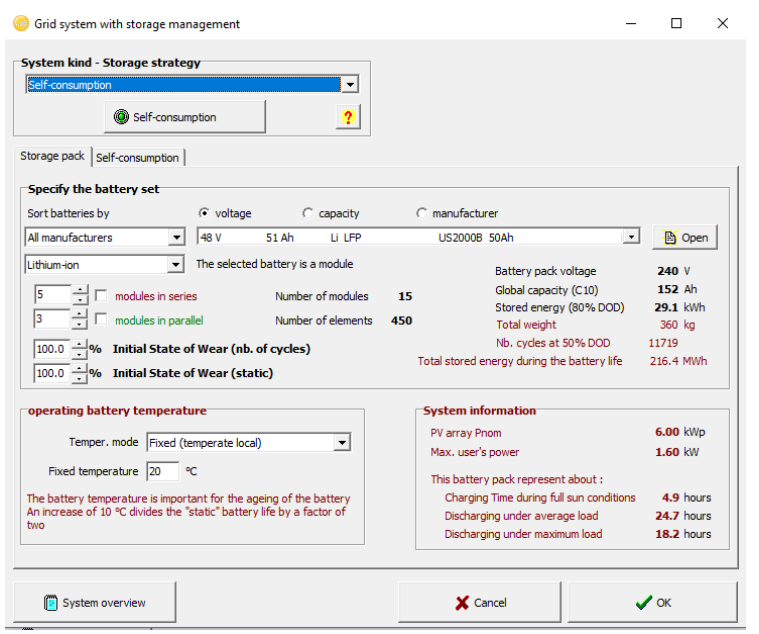

Gambar 14. Siklus pembebanan di kantin FTUI

\section{HASIL dan PEMBAHASAN}

\subsection{Rata-Rata Penggunaan Daya Hari kerja}

Rata-rata penggunaan daya pada hari kerja di kantin FTUI ditunjukkan pada Gambar 15. Terlihat bahwa beban maksimum terjadi pada jam 18.00 dimana daya terukur hingga 4,649 $\mathrm{kW}$.

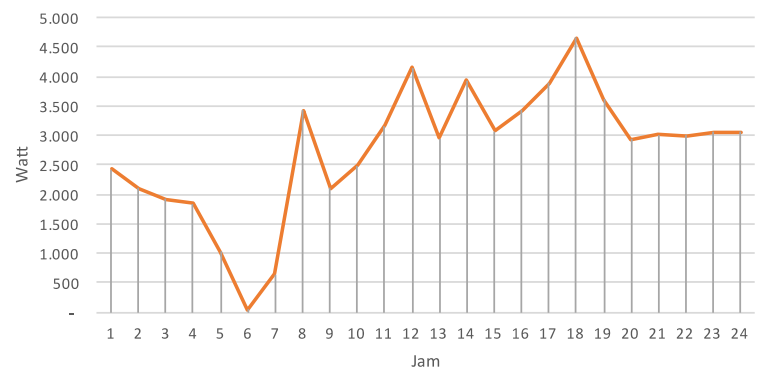

Gambar 15. Rata-rata penggunaan daya hari kerja pada Kantin FTUI 
Grafik menunjukkan bahwa intensitas aktifitas pada kantin meningkat pada saat kantin dibuka hingga tutup, hal ini disebabkan aktifitas penjual makanan dan mahasiswa pada kantin berlangsung pada retang waktu 07.00 pagi hingga 18.00 sore. Tetapi penggunaan daya lampu dan kulkas tetap berlangsung pada malam hari karena lampu digunakan untuk menerangi daerah kantin pada malam hari dan kulkas tetap harus mendinginkan minuman dan makanan selama 24 jam.

\subsection{Rata-Rata Beban Daya Hari Libur}

Rata-rata penggunaan daya pada hari libur di kantin FTUI ditunjukkan pada Gambar 16. Terlihat bahwa beban maksimum terjadi pada jam 21.00 dimana daya terukur hingga $1,8 \mathrm{~kW}$.

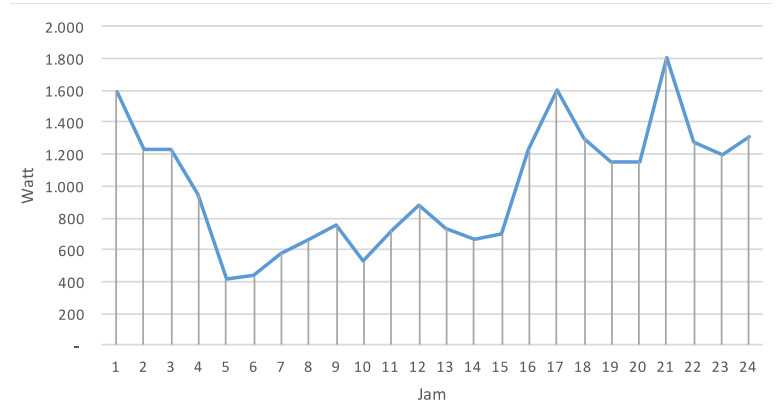

Gambar 16. Rata-rata penggunaan daya hari libur pada Kantin FTUI

Terlihat bahwa rata-rata penggunaan daya pada hari libur lebih kecil dibanding pada hari kerja. Hal ini kemungkinan dikarenakan intensitas aktifitas pada kantin FTUI saat hari libur sangat minim dibandingkan hari kerja.

\subsection{Analisis kinerja konfigurasi PLTS dengan simulasi PVsyst}

1. Kontribusi konfigurasi PLTS Berdasarkan Beban Harian

Gambar 17 menunjukkan bahwa energi yang dibangkitkan oleh konfigurasi PLTS berdasarkan beban harian secara on-grid adalah sebesar 22.409 kWh tiap tahunnya, sedangkan penggunaan battery backup pada konfigurasi ini menghasilkan energi sebesar $20.553 \mathrm{kWh}$ tiap tahunnya. Maka kontribusi energi terhadap beban oleh konfigurasi PLTS berdasarkan beban harian secara on-grid pada kantin FTUI adalah sebesar 96,20\% pada hari kerja dan $254,54 \%$ pada hari libur. Dengan penggunaan battery backup pada konfigurasi ini menghasilkan kontribusi sebesar $91,51 \%$ pada hari kerja dan $241,69 \%$ pada hari libur.

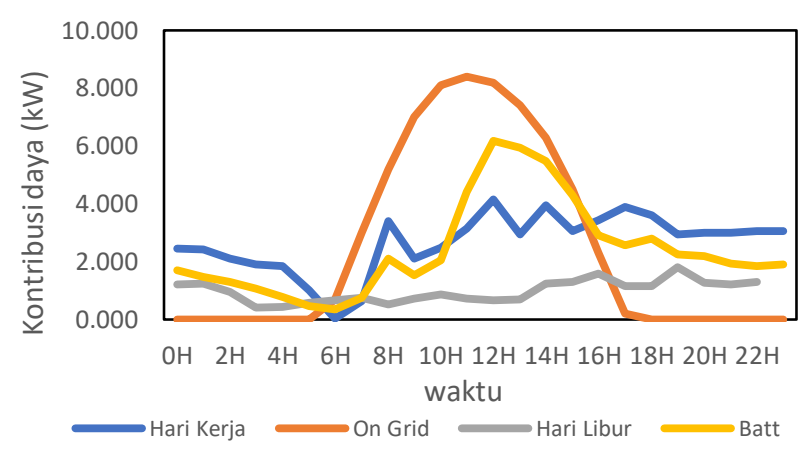

Gambar 17. Kontribusi Energi PLTS Berdasarkan Beban Harian

Potensi penghematan biaya listrik dengan konfigurasi PLTS berdasarkan beban harian secara on grid adalah sebesar Rp 1.213.821,00 tiap bulannya, dan total sebesar Rp 14.565.850,00 tiap dalam 1 tahun, dan dengan penggunaan battery backup menghasilkan sebanyak Rp 1.113.179,00 tiap bulannya, dan total sebesar Rp 13.359.450,00 tiap dalam 1 tahun.

2. Kontribusi konfigurasi PLTS Berdasarkan Luas Area Tersedia

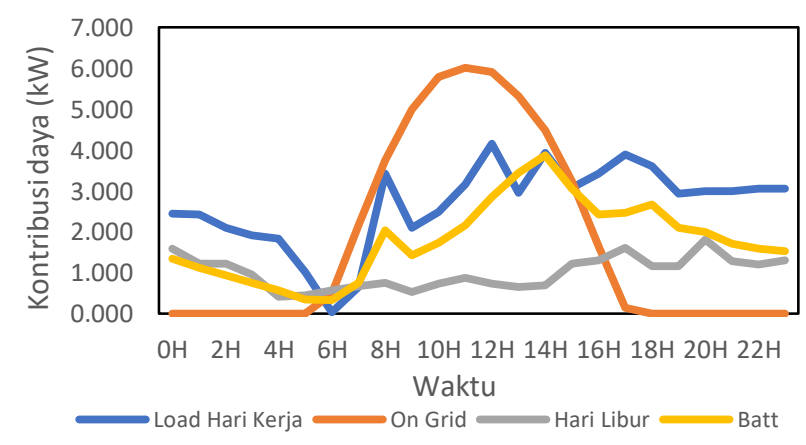

Gambar 18. Kontribusi Energi PLTS Berdasarkan Area Yang Tersedia

Gambar 18 menunjukkan bahwa energi yang dibangkitkan oleh konfigurasi PV berdasarkan luas area tersedia secara on-grid adalah sebesar $16.063 \mathrm{kWh}$ tiap tahunnya, sedangkan penggunaan battery backup pada konfigurasi ini menghasilkan energi sebesar $15.100 \mathrm{kWh}$ tiap tahunnya. Maka kontribusi energi terhadap beban oleh konfigurasi PLTS berdasarkan luas area yang tersedia secara on-grid pada Kantin FTUI adalah sebesar $68,98 \%$ pada hari kerja dan $182,18 \%$ pada hari libur. Dengan penggunaan battery backup pada konfigurasi ini menghasilkan kontribusi sebesar $68,98 \%$ pada hari kerja dan $179,27 \%$ pada hari libur.

Potensi penghematan biaya PLN oleh konfigurasi PV berdasarkan luas area tersedia secara on grid adalah sebesar Rp 870.133,30 tiap bulannya, dan total sebesar 
Rp 10.440.950,00 tiap dalam 1 tahun, dan dengan penggunaan battery backup menghasilkan sebanyak Rp 817.916,70 tiap bulannya, dan total sebesar Rp 9.815.000,00 tiap dalam 1 tahun.

\section{KESIMPULAN}

Beberapa hal yang dapat disimpulkan berdasarkan analisis yang telah dilakukan terkait dengan penyusunan PLTS adalah konfigurasi PV yang akan dipasang ditentukan oleh luasan area tersedia untuk pemasangan PV secara on-grid. Hal ini merupakan pilihan yang lebih baik untuk digunakan pada Kantin FTUI dikarenakan jumlah modul yang akan dipasang cocok dengan luas atap yang tersedia, sehingga tidak diperlukan penambahan dudukan PV yang akan menambah biaya konstruksi. Selain itu, jumlah komponen sistem yang lebih ringkas, dan penggunaan baterai tidak terlalu diperlukan karena baterai yang digunakan hanya bersifat sebagai energi cadangan atau Uninterruptable Power Supply (UPS).

\section{UCAPAN TERIMAKASIH}

Ucapan terima kasih kami sampaikan kepada Universitas Indonesia yang telah membiayai penelitian ini melalui program HIBAH PITTA B 2019 No. NKB0729/UN2.R3.1/HKP.0 5.00/2019

\section{DAFTAR PUSTAKA}

[1] https://www.un.org/development/desa/disabilitie s/envision 2030.html (diakses pada tanggal 24th Feb 2020)

[2] Y. M. Atwa, E. F. El-Saadany, M. M. A. Salama and R. Seethapathy, "Optimal Renewable Resources Mix for Distribution System Energy Loss Minimization," in IEEE Transactions on Power Systems, vol. 25, no. 1, pp. 360-370, Feb. 2010.

[3] Y. Cui, J. Zhu, F. Meng, S. Zoras, J. McKechnie, and J. Chu, "Energy assessment and economic sensitivity analysis of a grid-connected photovoltaic system," in Renewable Energy, vol 150, pp 101-115, 2020.

[4] http://iesr.or.id/pustaka/residential-rooftop-solarpotential-in-34-provinces-in-indonesia/ (diakses pada tanggal 20th Feb 2020)

[5] https://oxfordbusinessgroup.com/analysis/indone sias-equatorial-location-asset-solar-energyprojects (diakses pada tanggal 20th Feb 2020)

[6] Rencana Usaha Penyediaan Tenaga Listrik (RUPTL) - PT PLN Persero 2019 - 2028

[7] E. M. Saber, S. E. Lee, S. Manthapuri, W. Yi, C. Deb, "PV (photovoltaics) performance evaluation and simulation-based energy yield prediction for tropical buildings," in Energy, vol 71, pp 588595, Jul 2014.

[8] Ali, G.M. Shafiullah, T. Urmee, "A preliminary feasibility of roof-mounted solar PV systems in the Maldives," in Renewable and Sustainable Energy Reviews, vol 83, pp 18-32, Mar 2018.

[9] N. Shabbir, M. Usman, M. Jawad, M. H. Zafar, M. N. Iqbal, L. Kütt, "Economic analysis and impact on national grid by domestic photovoltaic system installations in Pakistan," in Renewable Energy, vol 153, pp 509-521, Jun 2020.

[10] M.J. Mangiante, P.Y. Whung, L. Zhou, R. Porter, A. Cepada, E. Campirano, D. Licon, R. Lawrence, M. Torres, "Economic and technical assessment of rooftop solar photovoltaic potential in Brownsville, Texas, U.S.A," in Computers, Environment and Urban Systems, vol 80, 101450, Mar 2020

[11] N. Mukisa, R. Zamora, T.T. Lie, "Feasibility assessment of grid-tied rooftop solar photovoltaic systems for industrial sector application in Uganda," in Sustainable Energy Technologies and Assessments, vol 32, pp 83-91, Apr 2019

[12] H Bimantoro et al 2019 IOP Conf. Ser.: Earth Environ. Sci. 353012005

[13] Hansen, Anca D skk. "Model for a Stand-Alone PV System." Roskilde: Risoe National Laboratory, 2000. 